\title{
Value Chain in the Visual Arts Market
}

\author{
Elio Amilcar Farfan Torrelles \\ Faculty of Economic and Social Sciences, University of Carabobo, Valencia, Venezuela
}

\section{Email address:}

eliofarfan@gmail.com

\section{To cite this article:}

Elio Amilcar Farfan Torrelles. Value Chain in the Visual Arts Market. Science Journal of Business and Management. Vol. 7, No. 6, 2019, pp. 164-172. doi: 10.11648/j.sjbm.20190706.15

Received: December 11, 2019; Accepted: December 17, 2019; Published: December 31, 2019

\begin{abstract}
The added value allows an asset or a service to meet a specific need. The value chain represents all those activities properly organized, which create these assets and services to make them available for final consumers. Documentary review has revealed that in the visual arts market these roles are not always adequately defined and often, the agents involved are unaware of their functions and responsibilities, generating aesthetic and financial distortions or imbalances that hinder this economic activity. This article aims to reveal this value chain as a way of legitimizing a piece of art as well as the benefits that some of these links have brought recently, given the new relationship between art and people. Such is the case of museums, especially the Guggenheim in Bilbao, with its positive impact on the economies of the communities that house them; art fairs, in the globalization of artists, works and aesthetic tendencies and art critics who influence the behavior of consumers and markets.
\end{abstract}

Keywords: Visual Arts Market, Piece of Art, Added Value, Value Chain, Legitimacy

\section{Introduction}

Before addressing the issue of the value chain in the art market it is necessary to establish the difference between the world of the visual arts and the visual arts market. The first relates to that area where the intellectual qualities of artists unfold and develop creative and aesthetic proposals. The second is where the artwork is traded: sold and bought for a specific sensorial or economic benefit.

Regarding the visual arts, The National Council for Culture and Arts in Chile, defined them as:

The visual arts imply the artistic production related to the creation of pieces that are essentially appreciated visually, such as paintings, photography, films, comics, installations, video art, among many others. This concept was introduced after World War II to name the new type of artistic production that had been developed since the advent of new media forms and the avant-garde breakthrough ideas. A large number of possible ways of making art would open as the production and classification criteria became more open and integrated. Around 1980, the term visual arts became more common as it is a more appropriate name for contemporary art, instead of plastic arts [1].

On the other hand, the assets and services that a society produces are designed to meet the needs of its members. Each of these products are justified (legitimized) as they turn into resources that enable the achievement of the objectives of each member of that society. When you are in the presence of primary requirements, it is easy to identify the reasons and the causes that motivate the consumption of those resources. Food, education, transport, housing are common examples of these assets, for which vast amounts of money are paid and no further explanation is required since everyone knows the reasons for their consumption.

We assume that in the world of visual arts, intellectual developments generate what we call pieces of art that involve personal, sensorial and material aspects and consider them "produced" by artists. Then, a problem of aesthetics and economic nature arises seeking to identify the reasons why they are created and the causes which impulse the exchange between different individuals. This task is far from simple. It is not easy to explain the reason for such events. Moreover, how to convince someone of the vital importance of creating a piece of art or acquiring it and treasure it or why some people offer pieces of art and why others request them. Which activities create the market of visual arts or how and why the art market is created.

Additional questions require answers as well, for example, what does each market agent involved offer throughout the 
entire process to promote the exchanges? Which activities increase the value of a piece of art? Moreover, when and why does a piece of art become a commodity, a tradable asset?

Then, it is necessary to identify the needs, motivations and impulses that trigger events within the world of art and create the market. This establishes the balance of coexisting interests that arise with the creation of the art piece until the moment of contemplation by sensitive viewers who may or may not be agents within the art market.

That is why this analysis is directed towards identifying the existing relationships between the visual arts and the exchange of assets and services in that area. The exchange process takes place not only between the artist, the piece and the final buyer, but also among all intermediate agents within the art market, the process by which the "piece" becomes a commodity and the visual arts turn into a profitable business for everyone. This aims to find out why so many individuals and organizations are found together around the world of visual arts to carry out numerous activities for economic and financial reasons.
In conclusion, the objective of this proposal is to identify the value chain of the art market as a way to legitimize a piece. This is done by discovering the roles of major market agents in the process. It also explains the results that this dynamic generates in activities such as pricing as well as viewing the visual arts as a commodity due to the presence of money in the world of fine arts and market changes.

\section{Added Value and the Value Chain}

The added value from an economic point of view and according to Rosenberg "is the increase in value, experienced by an asset or product during the process of production or manufacture" [2]. In other words, it is all those resources that are added to an asset or service in a production process or in a market, to meet a specific need. These resources may be material, labor, design, transportation, packaging, expertise or effort to allow such assets or services to be exchanged, consumed or used.

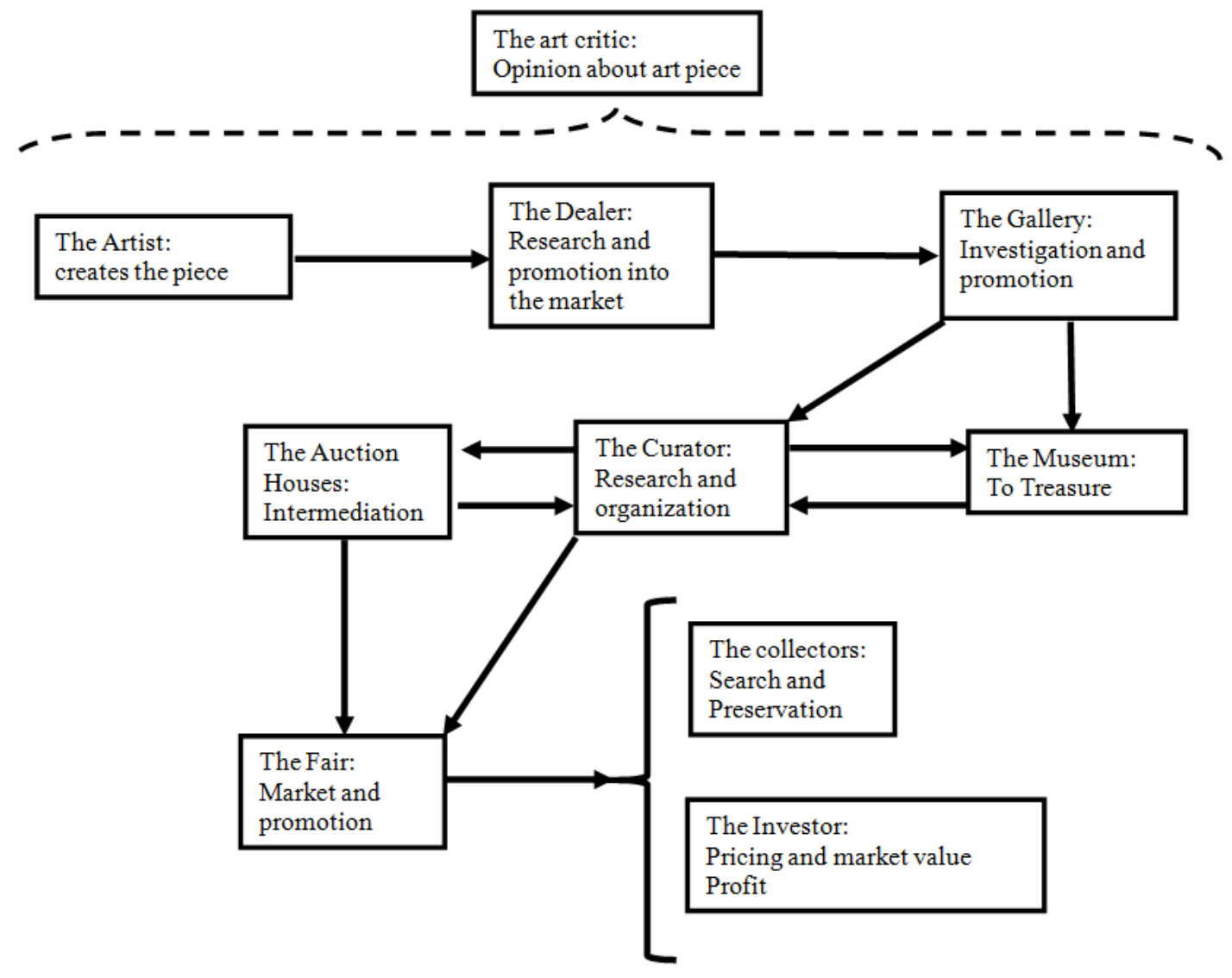

Source: The Author.

Figure 1. The value chain within the visual arts market.

The concept of the value chain was originally used in manufacturing companies but due to its rapid spread in communities and business management, its application extended to other areas, including markets.

According to Porter "Every company consists of a set of activities such as product design, production, marketing, delivering and support. All these strings can be represented using a value chain." (P. 52) [3]. And Porter continues saying that "the value chain of a company is embedded in a field of activities that I call a value system"[3].

This is why the company is not isolated in its field; rather, it participates in an economic process that consists of a 
complex network of companies, suppliers, agents, institutions and buyers that drive its operations. Then, each of these elements or agents of the economic conglomerate possess its own value chain, but is "connected" with that of other entities. This involves, among others, suppliers, the company itself, distribution channels, competitors, regulatory institutions and clients.

A market has two primary and opposing objectives that converge on an agreement to exchange which involves producers who want to sell their assets or services and buyers who want to meet their needs. To achieve these objectives, all the different value chains present participate and each adds to that end. They are also present in the art market, where its links facilitate the factors that permit the market to operate.

The study of the value chain in the art market is based on this review by Azpiroz. He states:

According to Eugenio Lopez, the value chain of art must consider three links: the artist himself - who must be recognized by his peers-, the museum curators - who might even reject exorbitant prices for some pieces - and finally the gallery [4]. Figuere 1 describes the value chain with its most outstanding elements.

From a general point of view Artprice says, "In short, with the museums, the galleries and the auction houses, art has become a vast domain for leisure, discovery, education and curiosity" (P. 3) [5].

In addition, Artprice continues, "the boom of museum exhibitions, the debate around derivative works and the fast rise of online sales, they all reflect an increasing public demand for cultural engagement and this new demand for higher standards of living may become a new economic drive for the auction industry."(P. 5) [5].

\section{The Most Important Roles in the Value Chain Within the Visual Arts Market}

This role, within a community or organization and its performance is represented by the development of the functions that are specific to each individual belonging to said community. In this regard Pavlosky, E. and De Brassi, J. C. indicate that:

The role theory from the perspective of functionalist sociology has been developed based on the concept of position: a position defines a minimum of mandatory behavior for the individual, but cannot guarantee that it will carry out such behavior perfectly. Considering this conception, role means the real performance of a person in a given situation. In other words, role is the way in which a person performs the requirements of his position. In turn, role is the dynamic aspect of status. This term refers to a kind of social identification mark that places individuals in relation to other individuals. How a person behaves will depend largely on the status he has, that is to say the particular position in his social environment [6]. According to Pavlosky, E., De Brassi, J. C. and Pichon Riviére, role is an organized model of behavior related to a certain position of the individual in an interaction network linked to his own expectations and those of others. (P. 58) [6].

To apply these concepts to the market of visual arts, and because of the complexity of the process, the focus will be directed only on the artist, the gallery, the museum, the curator, the art dealer, collector, investor, fair, auction house and the art critic as parts of that value chain. See figure 1.

What their duties are, their added value and their connections with the rest of the elements are some of the answers that will be shown below through the description of the responsibilities and basic behaviors of each market agent and its role, taking into account that the relations among them are not linear. However, we will try to systematize the process of legitimating a piece of art through the value chain.

\subsection{The Artist}

He is the producer (creator) of the asset to be traded in the market. He places randomly but harmoniously, all available materials, in an order that reflects the rules of his imagination to bear fruit to his artistic creation. He adds materials and aesthetic value to the raw material and turns it into a piece of art according to canons set by the community that will require them. This will be his contribution to the value chain of the market, but possibly the piece in his studio may not mean anything to those interested in this type of product. In this sense, the words of the famous Venezuelan artist Carlos Cruz Diez are eloquent, when he said in an interview: "I have been coherent and insistent. There is the present and the right time. If I had done this in Venezuela, it would not have worked. It was not the place. Now, how did I sense that here (Paris) was the place? You can have great ideas but may not be in the right place, or you say it before or after. It is condition. I do not believe in luck, I believe in being effective. One does not work to get rich, one works for the audience. I came to present a discourse, to be heard. (In Venezuela) I felt isolated; I wanted to say something, so I came to France. I made a great effort to say what I meant and be heard. But you must be coherent to make yourself heard. Because art is intangible. You can say as Duchamp, that anything is art, but if it is not well argued and you do not defend your truth, and contradict yourself, no one will believe in you. Moreover, he continues saying, "The desire of all artists is to reveal something new, and that is what the world's museums treasure" [7].

In other words AMMA \& Artprice states, “...But international recognition is one of the best indicators of their place and their importance in Art History" [8].

Therefore, this gives us several examples of what an artist must bring as added value, revealing something new, being in the present and right time, being effective, working for the audience (the art world), presenting a discourse to be heard, and being coherent and insistent, "because art is intangible". Finally, art should be well supported, so we could say that there is no art without an audience. The artist generates creation and aesthetics as an added value to the market, as part of the value chain. 


\subsection{The Gallery}

The description of the role of the gallery will start with the story that Azpiroz told the Mexican collector Eugenio López:

Three years ago, I spent a few days in London and every day I returned to the hotel, I saw a gallery showing an exhibition. In the end, I realized that it was the work of Gabriel Guzmán. I entered the gallery and bought a piece. They asked why I bought that piece in London when I could buy it in Mexico. Very simple: if I do not show support in London to a Mexican artist, the gallery will not give him another exhibit in the future. Why is it important that a London gallery exhibit the work of a Mexican artist? Because it promotes him, getting him close to other buyers, thus making him universal [4].

When Artprice interviewed Eric Dereumaux, director of the RX Gallery (Paris) he indicated, "For the art and through the gallery, I seek, encounter, travel, discover, meet, share, promote, optimize, experiment." (P. 51) [9].

Artprice continues with Amy, director of the Amy Li Gallery (Pekin) who says, "What I seek for since I opened my gallery is to be a platform for contemporary art that laughs at cultural boundaries, to organize exhibitions as rich and varied as possible, bringing together different cultures and fields of creativity" (P. 52) [9].

Artprice with Pearl Lam, director of the Pearl Lam Gallery (Shanghai, Hong Kong, Singapore), who said, "The process of building the reputation of an artist and presenting him to the market is another aspect of art dealing I particularly appreciate." (P. 52) [9].

The above quotations clearly outline the added value of galleries. In short, they include activities such as discovering and making an artist's work known, which they first studied and researched, creating his image and introducing him to the market. Therefore, research and propagation is what galleries offer to the value chain of the art market.

\subsection{The Museum}

The memory of society. As for the description of the added value of the museum, we begin with words of Carlos Cruz Diez, when he says, "The desire of every artist is to reveal something new, and that's what the world's museums treasure" [7]. To treasure implies accumulation and wealth. In addition to this concept, Suazo adds the following:

Considering it a deposit for cultural assets, it works like a bank vault, protecting and enhancing the symbolic value of those assets. As a result, the museum institution has become the most influential mechanism of artistic consecration, being the undisputed guarantor of that kind of "added value" held by the objects deposited there. A value that is not only linked to the age of the pieces or their aesthetic significance, but also to the fluctuations of "market review" and taste trends. (P. 28) [10].

Then the museum, as part of the value chain of the art market, is the guardian of the pieces and the cultural memory, in short, the one that holds and makes a piece of art and the artist's career known to the public.
In addition, a museum is a remarkable economic factor that generates jobs and prosperity within the community, as Lipovetsky, G. points out: the Guggenheim was built in Bilbao and thanks to the museum, the city has experienced a rebirth becoming the second tourist destination in Spain. Museums have a huge impact on economic life. [11].

\subsection{The Curator}

He investigates in the art world the production of the different artists and organizes trade fairs and art exhibitions in museums, galleries and art fairs. Suazo is more precise regarding the subject when he states the following:

It is also an intermediary professional practice, closely linked to being an art critic, that adds a greater degree of specialization in the field of cultural diffusion. Its basic function is to promote a coherent and orientated reading of the art production that includes the design of exhibitions and the principles that guide the creation of institutional, corporate and private collections. (P. 80) [10].

Therefore, we have research, guide and organization as the elements that the curator adds to the value chain.

\subsection{The Art Dealer}

The art dealer closely resembles the work performed by the promoter of new companies or new investments in the capital market. They research which pieces and artists, according to their opinion, are most likely to be "placed on the market" and sold because they represent an important new aesthetic proposal within the artistic movement. Teo Van Goch and Amboise Vollard, Picasso's dealers, are perhaps the most famous in the business. They connect a specific buyer with the artist and the corresponding piece. Their job involves finding both the piece and the artist as well as the appropriate buyer who specializes in a particular trend. Patience and credibility in their work could be the elements that define the presence of the dealer in the value chain of the art market, as well as research of new productions of artists and their promotion.

\subsection{The Collector}

To describe the collector as a link in the chain we will rely on Artprice's interview to four collectors Pernull Karl (Austria), David Brolliet (Switzerland), Jeff Leatham (USA), and Bernard Magrez (France), highlighting predominantly two words: passion and emotion [9]. However, due to its subjectivity, this does not affect the value chain. However, in collecting, as in museums, what stands out is its almost instinctive nature to treasure pieces of art to preserve them although they may not be on display to the public.

Suazo rightly says regarding the above, "the act of collecting is not the sole competence of a specialized sector, but a well established activity within human behavior" [10]. However, the collector is motivated by the passion for beauty, his actions legitimate the piece of art in the market and his "accumulation" of art has an important difference from the "treasuring" of the museum, as the former rests in 
the privacy of vaults, while the second is shared with the public. Search and perseverance would be his most important contributions.

Aditionally, from an economic point of view, treasuring a work of art can give it a quality of "freshness" in the market, making it something exceptional for which important sums of money could be paid. As Gilardoni, M. puts it, "in addition to the quality of the pieces, one of the great attractions of the collection initiated by Rafael Cuneo and continued by his successors - a family of agricultural producers from Entre Ríos - was that it consisted of "fresh paints" in the jargon of specialists, a name they give to pieces that have been absent from the market for a long time, in this case about 70 years" [12].

\subsection{The Investor}

Unlike the collector, the investor does not treasure; he buys to sell in the short, medium and long term (depending on the conditions of the market) to make a profit, a financial gain. As for the value chain, the investor provides the market value to carry out the transactions specifying the price and participating in the trade flow of assets and money. His contributions would be pricing and market value.

\subsection{Auction Houses}

They are essentially sales agents of art pieces, connecting buyers and sellers and receiving a commission in return. They represent the legal and structured secondary market through which the most important transactions in art around the world are carried out with Christie's and Sotheby's as the most important worldwide. Due to competition in the market, these institutions have also included the selection of quality products in their catalogs as part of their duties. According to Artprice:... they have significantly expanded their areas of competence: marketing development, direct sales, organization of curated exhibitions, large digital investments, strategic reinforcement in Asia and in other promising areas for the art market, such as the Middle East and Brazil. Many essential investments to remain competitive and to anticipate market developments. They apply an aggressive international development policy and this geographical expansion allows them to increase their means to succeed. They consider necessary to strengthen their relations with collectors in all major and emerging markets (P. 18) [9].

Intermediation and an organized market correspond to the most important contributions offered by auction houses to the value chain of the art market.

\subsection{The Art Fair}

A fair is basically a market, a place where buyers and sellers exchange assets and services. It is also a market reinforced with all kinds of shows: musicals, movies, competitions, theater, etc.

Art fairs are organized so that dealers and galleries offer the art pieces from the artists they represent, seeking to promote them and sell them to interested collectors, investors and institutions. However, their contribution is not limited to only the art business, they also manage to have lecturers, curators and specialists who offer conferences and forums giving a wide and detailed description of artists' profiles and their pieces thus helping them to become well-known. An important function of art fairs is that they attract nonspecialized public and connect it to the art world, managing to stimulate the taste and art appreciation in the population. These fairs are usually international, which results in the generation of side businesses such as lodging, travel and tourism in general, which is particularly attractive for the cities where these events take place. According to Laso (a) art fairs started, as we know them today with Art Cologne in the 60 s of last century, then Art Basel followed, the most important of our times, FIAC in Bologna and Arco in Madrid [13]. The globalization of the art fairs emerges as one of its most important features, connecting agents worldwide around the legitimate business of art.

Summarizing, it can be said that as for the value chain, the art fair advances the market not only by positioning the art pieces to be purchased, but also by contributing pertinent information of the sector, thereby increasing the contact of art, globalization and collateral business. Marketing and Positioning of art pieces would be its contributions. All these "links" legitimize the piece of art in the market as "collective added value", its individual contribution place the piece of art on a higher level.

\subsection{The Art Critic}

According to Burton, K. D. art criticism is the analysis and evaluation of works of art. More subtly, art criticism is often tied to theory; it is interpretative, involving an effort to understand a particular work of art from a theoretical perspective and to establish its significance in the history of art [14] Many times, their opinions direct or modify the behavior of art market agents, either to promote or hinder a particular work or artist. This concept is reinforced in the words of El Nacional: It is inevitable to glimpse some slits through which lines of explicit correspondence between art criticism and the quotations of an artist's work can be filtered. Specifically, we think of the prices that are awarded in salons, biennials or exhibitions of confrontation in general. Also, an invitation to participate in some relevant collective exhibition contributes to support a creator's resumé. Of course, in this account we should not leave out the influence of a good evaluation text on which the legitimizing scope and the meaning of a trajectory is based [15].

\section{The Legitimacy of the Artwork}

In many analyses of any given piece from a particular artist, the word "legitimacy" can express its value as an asset within a community. This value can be just for sensory gratification, but does not necessarily imply a monetary value. In fact, according to many experts in visual arts, there may be pieces whose price in monetary terms do not reflect their artistic value. 
According to the Real Academia Española, legitimate is what is right, genuine and true in any line. Legitimating, by extension, would be the process by which something becomes, or is made legitimate. It is the recognition granted to something, an object, a person, a process or anything else that is true or real [16].

\subsection{Reasons to Legitimize an Artwork}

An artist should be recognized and accepted by his peers and by other stakeholders who will verify the authenticity of a piece, not only as being his own, but also as something new, different and important within the pictorial activity.

\subsection{Legitimization Process}

The aesthetic contribution, technique and innovation of an art piece are evaluated.

\subsection{Agents in Charge of Legitimizing an Artwork}

Legitimacy within the art world is done, firstly, by the community of artists, colleagues of the artist who produced the piece, then there is the opinion of experts such as curators, galleries, art critics, collectors, investors and museums, that is to say by each of the elements that make up the value chain. Generally the opinion of art critics has a significant weight among buyers when acquiring a work of art. However, the words of Suazo, F. are important to clarify this criterion, when he expresses that: Now, the criterion is formed with information and knowledge. And therefore, the critical activity has a decisive role as one of the referents (although not the only one) to pay attention to when a work is acquired. Therefore, it would be excessive to only blame critics for market behavior. Other considerations apply, for example, it would be good to know if there is sufficient demand for the artistic offer, if what is offered meets the expectations of potential stakeholders, if what the critic considers most relevant is sufficiently argued, etc. Let us not forget that the market does not work philanthropically, but based on profit criteria (material and symbolic) for everyone involved in an artistic transaction [17].

\subsection{Relationship Between Legitimacy, Value and Price of the Artwork}

In the world of visual arts, the value of an art piece is measured within aesthetic, creative and innovation parameters, while in the market it is measured by the price. Each approval or endorsement granted by the "chain links" is a guarantee that the "product", the piece of art, is genuine and can be sold and bought by consumers. Every time the piece is mentioned in catalogs, exhibited in halls and galleries, acquired by stakeholders, sold and re-purchased, it receives the quality of being genuine and significant, all of which will be translated to the cost of the piece.

\section{Pricing}

Assigning a price to an asset in a given market is a complex process since not only the costs of raw materials, labor, indirect costs and other expenses of the distribution channel must be considered. Other aspects include external variables such as prices of competitors selling similar products, the advantages and disadvantages compared to competition, whether it is a new product to be promoted intensely, consuming time and financial resources and other specific variables for each specific case. Therefore, defining a starting price is a difficult task.

Considering that price assignment of any product or service is not easy, it gets much more difficult when it comes to the visual arts. Here, other factors intervene such as geographical location (proximity or remoteness from the centers of interest) or the death of the artist. For example, let us consider how much the artist J. M. Basquiat (1987) could have spent on materials for his painting "The Boxer." If he invested one thousand dollars at the time, why was the painting sold for $\$ 70$ million in 1993? On the other hand, why did the aesthetic ideas and innovation of the artist's work give it such significance and quality that the art world was so delighted that its value, not price, was equivalent to 70 million dollars?

That is, the community interested in the pictorial proposal of the asset, was willing to pay that amount regardless of the cost to the "producer" from a realistic point of view.

This recognition of the piece, through the payment of $\$ 70$ million, represents its legitimacy within the interested community (the art world) and the market. Experts and stakeholders who recognize unquestionable qualities of art in the product endorse this legitimacy, stating reasons, principles and values, which according to their own conventions, are valid.

Of course, when assigning prices, mistakes can occur. This applies to those pieces with poor intellectual contribution even though some market agent might have paid a high amount for them. Here is when the world of art must correct this situation by considering technique, aesthetics or the intellectual creation of the producer.

This shows us that there must be a balance among aesthetic contribution, pictorial technique and beauty. The value of the piece is translated into monetary terms and if the balance is broken, there is a distortion.

Regarding the price behavior of the products (the visual art pieces) in the market, we can refer to the concepts of perfect competition, in the form of monopolistic competition. At this point, it is important what Samuelson expresses: "If a company can significantly influence the market price of its product, it is classified as an "imperfect competitor". (p. 142) and "... the monopolistic competition occurs when a large number of vendors produce differentiated goods"... where "the products sold by different companies are not identical. (P. 143) [18]. Adapting these concepts to the art market, we could identify many producers or artists with clearly differentiated goods or art pieces, where the ability of some agents (artists, galleries, auction houses, collectors or investors) can significantly influence the price.

With New York in the early 80 s as a background and with 
possible references to Andy Warhol and Jean Michel Basquiat, Guasch, A. M., shares his point of view about the value of the pieces in these words:

The value of art pieces were measured in the market along with other goods and fantasies, and their prices were no longer dependent only on such modern notions as intrinsic excellence or uniqueness. Moreover, extrinsic factors such as appetite -previously associated with sexual possession, later applied to the possession of wealth and inanimate objects governed purchase transactions of pieces by living artists worth millions of dollars worldwide. (P. 251) [19].

When it comes to the price and the market, the words of Nuñez, S., C. F. and Alias, G., J. A. are interesting, when they state in their particular form of expression:

Behind that mechanical snobbery, there is actually an increased strength of the object, its image, the sign, the simulation, and at the same time, an increased strength in value, being the art market the best example. We are far from price alienation, which remains a true measure of things. We are in the ecstasy of value, which makes the market notion explode and at the same time destroy the artwork itself. (P. 185) [20].

\subsection{Visual Arts as a Commodity}

A commodity is an asset or a service that meets a particular need and is exchanged for money. Huls, T. talks about this topic, "What, then, makes a thing a commodity. A comodity is a thing that has use value and can be exchanged..." [21]. In the art market, each member of the value chain has a particular interest in that the art piece becomes a commodity, including collectors. Otherwise, the piece of art, the product, would be confined within the boundaries of the art world just by its aesthetic and creative qualities, but without generating any practical benefit to the rest of society. No sum, large or small would be paid for those pieces, nor would that enormous economic activity take place.

In regards to this concept, the following words from Peraza, M. Iturbe, J., highlight the difference between the art world and the art market, as follows:

We will name the piece of art an artistic product once it has left the hand of its creator and takes part in the market. It is at that point, when it is no longer an object that it actually becomes an artistic product, in fact, a synonym of merchandise, since it already has a price. The artistic product is not only likely to change ownership; it also becomes part of a whole world of production and acquisition of historical, stylistic or speculative virtues. For us, the artistic product, and not the artistic object, is the issue to study without any negative consideration. (P. 13 and 14) [22].

However, a big problem remains which the market and each of the members of the value chain must address. There is a great difference in the distribution of earnings, starting with the prices that are paid to producers in the primary market and then the huge sums of money often involved in both overall prices and fees in the secondary market.

In this respect, those responsible for solving the problem have to take into account PIAMO's interview to a young Venezuelan painter, Gustavo Silva Nunez:

What do you not like about the art world? "That elite group that is made up of artists who are valued by the price of their pieces. Art is not about reaching that point of class and distinction, when that happens the meaning of art is lost "[23].

On the other hand, the fact that a piece of art, such as the Mona Lisa by Leonardo Da Vinci, is a commodity of free trading on the market, should not be cause for anguish. This means that all the resources used to produce it will be duly paid, without going into the details of the distribution of wealth, and that once charged or paid for, these resources will return to their "owners", allowing them to remain in the pictorial activity and generate more "products" for the delight of consumers.

\subsection{Money and Arts: From The Caves of Altamira to Basquiat}

One of the significant and controversial differences between the art world and the art market is money, translated into economic and financial qualities acquired by the pieces of art once exposed to the market forces, supply and demand. This is a thin line between two different forms of expression and behaviors and to avoid confusion they must be assessed in the true aesthetic, creative, financial and trading dimensions each party owns.

Unfortunately, for many people, finances and visual arts represent conflicting interests that cannot be reconciled. However, throughout history there are examples of artists who have charged for their work and who have legitimately obtained large sums of money for their intellectual creations. Many reasons justify this practice, but it suffices to say that artists, like any other human being, must earn a living by relying on their skills.

In 1879, Don Marcelino de Sortuolo discovered the cave paintings in the Caves of Altamira in Spain. The reasons why one of our ancestors was motivated to create these paintings are unknown. We do not know if these were exchanged for skins, bones or authority. The truth is that they are the testimony of an intellectual and creative activity, but they are not commodities because they cannot be bought or sold. The relationship between art and the exchange of commodities has always existed. During the Renaissance in Italy, artistic creation and patronage began a long road to this day. Leonardo Da Vinci, Michael Angelo Buonarroti and many others, charged money to finance their professions.

El Greco is a tangible example of the need of artists to charge for their creations and concrete evidence that this practice has always been carried out. For example, 24,000 reals and 1,600 ducats were paid respectively for the pieces The Burial of Count Orgaz (1586-1588, Santo Tomé, Toledo), besides the main altarpiece, and two laterals for the church of Santo Domingo el Antiguo in Toledo. Additionally, Laso's words are interesting (b) in respect to an information on the sale of the "Caprichos de Goya", which stipulate: 
Collection of pictures of capricious matters invented and etched by Francisco de Goya. Sold on Desengaño Street No. 1 , a perfumes and liquor store, paying 320 reals for each collection of 80 prints [24].

In regards to this matter, we bring Azpiroz again, referring to the statement by Eugenio Lopez:

"An artist is someone who does what he really wants to do, in any way", says Eugenio, who acknowledges that the art market is not an exact science, but the opposite: "There are artists who get stratospheric prices at an auction. What holds them? Only two people competing fiercely for a piece. Anyway, you cannot take the monetary value away from a piece, because without it neither the gallery, nor the curator can live, the art would not transcend" [4].

In addition, many of them hired students and assistants that helped them in the development of their creations and were substituted frequently, especially in the production of serial pieces. So why is there so much controversy over the fact that art pieces are a commodity in this consumer society?

\section{The Market Changed}

And also the art world. Velthuis describes this when he says:

The contemporary art market is in a changing process, or so it seems. Especially over the last two decades new institutions have appeared, while the power dynamics among the existing ones has changed. Artists and collectors from emerging economies in Asia and Latin America are making rapid progress in the field of global art, resulting in an ever-changing art market. New digital technologies are reshaping the ways to commercialize art: the first art fairs online are working, as discussed by Noah Horowitz in this volume, and especially at the top of the market, sales are taking place on a regular basis through dealers who send JPGs to anonymous collectors. The role of the experts in the art market has changed as well. There has also been much less influence by public museums and other institutions who have no monetary interests, while the control of increasingly wealthy private collectors over artists' careers and over the assessment system in the art world is getting stronger [25].

It could not be otherwise, since everyday life was radically changed by technology. That is why the old forms of exchange of both information and goods, financial flows and the relationships between the different members of the value chain have been modified giving way to new institutions and new types of transactions.

\section{Conclusions}

In the art market, the work of art is merchandise that can be sold, bought and sold again, that is, traded in a market. This process is materialized through a value chain in the art market, where each link in the chain provides the work of art a particular added value and the sum of the different added values legitimize the work of art, the market value and the price, being these some of the benefits generated by this value chain.

Finally, the art world and the art market can coexist without major problems and, in addition, they can obtain mutual benefits that result in greater and better aesthetic and artistic proposals with their corresponding economic utility. Art history is the product of a strong work of genius artists supported by market finances, a strong relationship between market and art.

\section{Acknowledgements}

I would like to acknowledge the valuable help of Felix Suazo and Nancy Farfan for their contribution on the market knowledge of contemporary art, which meant the base to complete this article. Likewise, I wish to thank Adda Morales for her help in the translation of this text.

\section{References}

[1] Consejo Nacional de la Cultura y las Artes. Gobierno de Chile. (2012). Glosario de Artes Visuales y Nuevos Medios. Valparaíso. Retrieved rom http://www.estaciondelasartes.com/wpcontent/uploads/2014/04/Glosario-Artes-Visuales-y-NuevosMedios.pdf.

[2] Rosenberg, J. M. (1992). Diccionario de administración y finanzas. Grupo Editorial Océano. Barcelona.

[3] Porter, Michael E. (1987). Ventaja Competitiva: Creación y Sostenimiento de un Desempeño Superior. 1era. edición. México. CECSA.

[4] Azpiroz, R. (2014). El coleccionista de arte más importante de América Latina Retrieved from http://www.forbes.com.mx/elcoleccionista-de-arte-mas-importante-de-america-latina/.

[5] Artprice. (2019). The art market in 2018. Retrieved from artprice.com.

[6] Pavlosky, E. y De Brassi, J. C. Lo Grupal. Devenires. Historia. Galerna-Búsqueda de Ayllu. Retrieved from https://books.google.es/books?id=oUmE30K_KygC\&pg=PA57 $\& \mathrm{dq}=$ concepto + de + rol $\&$ hl $=$ es-

419\&sa $=$ X\&ved $=0$ CDsQ6AEwBWoVChMI9dv5vZDZxwIV0 $7 \mathrm{geCh} 3 \mathrm{IoQ} 6 \mathrm{e} \# \mathrm{v}=$ onepage $\& \mathrm{q}=$ concepto $\% 20 \mathrm{de} \% 20$ rol $\& \mathrm{f}=$ false.

[7] Cruz D., Carlos (2015). Me duele profundamente que en mi obra se despidan del país. Dolar Today, Retrieved from https://cloud-1420216451-cache.cdn-max.com/carlos-cruz-diezduele-profundamente-que-en-mi-obra-se-despidan-del-pais/.

[8] AMMA \& Artprice. (2018). The Art Market Report in 2018. Retrieved from https://www.artprice.com/artprice-reports/theart-market-in-2018.

[9] Artprice. (2013). El mercado del arte Contemporáneo. (Informe anual Art Price 2013). Lyon. Artprice. Retrieved from http://imgpublic.artprice.com/pdf/artprice-contemporary2012-2013-es.pdf.

[10] Suazo, Félix (2013). Umbrales de la museología. 1era. edición. Caracas. El Ane.xo. 
[11] Lipovetsky, G. (2018). El mercado del arte se ha convertido en un lugar de especulación. Retrieved from https://www.abc.es/cultura/abci-gilles-lipovetsky-mercadoarte-convertido-lugar-especulacion201805200216 noticia.html\#ns campaign=rrssinducido\&ns_mchannel=abces\&ns source $=$ wh\&ns linkname $=$ noticia.entrevista\&ns fee $=$ 0 .

[12] Gilardoni, M. (2019). Dos Monet, un Modigliani y un Pisarro. Trastiendaplus. Buenos Aires, Argentina. Retrieved from http://trastiendaplus.com/dos-monet-un-modigliani-y-unpisarro-provenientes-de-coleccion-argentina-se-vendieron-elmiercoles-pasado-en-66-millones-de-dolares/.

[13] Lasso, S. (a). Las 10 ferias de arte más importantes del mundo. Retrieved from http://arte.about.com/od/Exposiciones-Y-Eventos/tp/LasFerias-De-Arte-Mas-Importantes-Del-Mundo.htm.

[14] Burton, K., D. Art criticism. Retrieved from https://www.britannica.com/art/art-criticism.

[15] El Nacional. (March, 2019) En el arte del mercado del arte, el arte es factor y la crítica soslayo. Retrieved from www.elnacional.com/noticias/papel-literario/arte-del-mercado-delarte-arte-factor-critica-soslayo_275818 7/11.

[16] Real Academia Española. Diccionario de la lengua española (Drae). 22 edicion. Retrieved from http://lema.rae.es/drae/?val=legitimo.

[17] Suazo, F. (Feb., 2019). Crítica y mercado (algunas consideraciones aplican). Trafico Visual. Caracas, Venezuela. Retrieved from https://www.traficovisual.com/2019/04/14/critica-y-mercadoalgunas-consideraciones-aplican-por-felix-suazo/.

[18] Samuelson, P.; Nordhaus, W. (2002). Economía. 10ma. Edición. Madrid. McGraw- Hill/Interamericana de España, S. A. U.

[19] Guash, A. M. (2000). Los manifiestos del arte postmoderno. Textos de exposiciones 1980-1995. Ediciones Akal, S. A. Retrieved
https://books.google.es/books?id=9fT sAFZBcEC\&pg=PA25 $1 \& \mathrm{dq}=\mathrm{la}+$ cadena $+\mathrm{de}+$ valor + en $+\mathrm{el}+$ mercado + del + arte $\&$ hl=es419\&sa $=$ X\&ved $=0$ CE4Q6AEwBjgeahUKEwjhuOGo93HAhWDmR4KHTtQBI8\#v=onepage $\& \mathrm{q}=\mathrm{la} \% 20 \mathrm{cad}$ ena $\% 20 \mathrm{de} \% 20$ valor $\% 20$ en $\% 20$ el $\% 20$ mercado $\% 20$ del $\% 20$ arte $\& \mathrm{f}=$ false.

[20] Núñez, S., C. F. y Alias, G., J. A. (2014). Estética: entre lo bello, lo feo y lo útil. Grupo Editorial Planeta Alvi, Ltda. San Juan. Retrieved from https://books.google.es/books?id=NbWsCQAAQBAJ\&pg=PA $185 \& \mathrm{dq}=\mathrm{la}+$ cadena $+\mathrm{de}+$ valor $+\mathrm{en}+\mathrm{el}+$ mercado $+\mathrm{del}+$ arte $\& \mathrm{hl}=$ es-

419\&sa $=$ X\&ved=0CFgQ6AEwCDgeahUKEwjt1_zf5uTHAh $\mathrm{XMJh} 4 \mathrm{KHXJmD} \mathrm{c} \# \mathrm{v}=$ onepage $\& \mathrm{q}=\mathrm{la} \% 20$ cadena $\% 20 \mathrm{de} \% 20$ valor $\% 20$ en $\% 20$ el $\% 20$ mercado $\% 20$ del $\% 20$ arte $\& \mathrm{f}=$ false.

[21] Huls, T. (2017). A History of the Western Art Market: A Sourcebook of Writings on Artists, Dealers and Markets. California University Press. California, USA. ISBN 9780520290631.

[22] Peraza, M. Iturbe, J. (1998). El arte del mercado en arte. Universidad iberoamericana. Mexico. Retrieved from https://books.google.es/books?id=NKVml4WXR$\mathrm{cC \& pg}=\mathrm{PA} 13 \& \mathrm{dq}=\mathrm{el}+\mathrm{valor}+$ dentro + del + mercado + del + arte \& $\mathrm{hl}=\mathrm{es}-$

419\&sa $=$ X\&ved $=0$ CC4Q6AEwAWoVChMIorTTqqbdxwIVB KceCh0mhA

$\mathrm{RT} \# \mathrm{v}=$ onepage $\& \mathrm{q}=\mathrm{el} \% 20 \mathrm{valor} \% 20 \mathrm{dentro} \% 20 \mathrm{del} \% 20 \mathrm{mercad}$ o\%20 del $\% 20$ arte \&f $=$ false.

[23] Piamo, R. (2015, 12 de abril). Gustavo Silva Núñez. Cuadros con vida propia. Revista Paréntesis. Edición aniversario. Diario El Carabobeño. Valencia.

[24] Lasso, S. (b). Anuncio original de la serie Caprichos de Goya. Retrieved from http://arte.about.com/od/Como-ComprarArte/fl/Anuncio-original-de-la-serie-Caprichos-de-Goya.htm.

[25] Velthuis, O. (2014, June, 15). El mercado de arte contemporáneo entre el estancamiento y el cambio. Denken pensé Thought Mysl. Servicio informativo del pensamiento cultural europeo. 